\title{
LIMFOMUL NON HODGKIN CA O MASĂ TUMORALĂ A BAZEI LIMBII: STUDIU CLINICOPATOLOGIC
}

Cuvinte cheie: baza limbii, limfom cu celule B, limfom cu celule T.

\section{Rezumat}

Fondul problemei: limfomul non Hodgkin (LNH) survine rar la baza limbii. Scopul studiului este de a investiga aspectele clinicopatologice la pacienții cu LNH al bazei limbii.

Metode: au fost analizate fișele electronice a 10 pacienți cu LNH primar la baza limbii, între 1997 și 2007, internați la un centru medical terțiar.

Rezultate: Pacienții au fost trei femei și șapte bărbați cu vârsta între 17 și 93 ani (mediana 62,5 ani). Simptomele lor au fost: disfagie, dispnee și sângerări în cavitatea bucală. La toți pacienții a fost identificată o masă tumorală a bazei limbii, prin folosirea unui endoscop larigian rigid sau flexibil, la șase pacienți având o localizare posterioara de epiglotă. Diagnosticul a fost confirmat prin examenul histopatologic, care a evidențiat la opt pacienți un limfom difuz cu celule B, iar la doi pacienți un limfom periferic cu celule T.

Concluzie: Deși LNH la baza limbii este rar, ar trebui luat în considerare în diagnosticul diferențial al tumorilor de bază de limbă.

\section{Introducere}

Studiile au arătat că în Statele Unite, 5-10\% din toate cazurile de limfom non Hodgkin primar sau secundar apar la nivelul inelului lui Waldeyer, care include tonsilele palatine, țesutul limfoid al nasofaringelui, palatului moale, și bazei limbii $[1,2]$. În Europa au fost raportate incidențe mai mari de 30 pînă la 50\%. Această diferență ar putea fi atribuită practicării biopsiei de rutină în Europa la nivelul inelului lui Waldeyer la toți pacienții cu LNH, sau unor caracteristici particulare, ori unor posibile influențe ale factorilor specifici etiologici și de mediu [1, 3, 4]. Aproximativ o treime din toate cazurile de LNH apar în țesuturi altele decât ale nodulilor limfatici, fiind denumite generic cu termenul de limfom extranodular [5, 6].

În inelul lui Waldeyer, amigdalele sunt cel mai frecvent afectate ( $40 \%$ până la $79 \%$ din toate leziunile primare). Depistarea unui LNH primar la baza limbii, palatului moale, sau diseminat în cavitatea bucală, este mai puțin obişnuită $[1,7,8]$. Inelul lui Waldeyer împărtăşeşte multe din tendințele histopatologice ale restului țesuturilor limfoide (mucosa-associated lymphoid tissue -MALT), de exemplu o frecvență crescută a limfomului difuz cu celule B şi o relativ rară incidență a limfomului folicular, în ciuda abundenței de foliculi limfoizi reactivi [9].

Din punct de vedere clinic leziunile tonsilare şi ale bazei limbii se caracterizează prin disfagie şi dispnee, limfoamele nasofaringiene fiind în mod obisnuit asociate cu simptome nazale, auditive şi ale nervilor cranieni. În studiul lui Batuccas Caletrio et al. [10], din 2005, cel mai frecvent semn al LNH la nivelul inelului Waldeyer a fost limfadenopatia cervicală.

Hipertrofia amigdalei linguale este cauzată în mod obișnuit de hiperplazia compensatorie post amigdalectomie. Totuși, atunci când ea se asociază cu dispnee progresivă și/sau disfagie, precum și cu o leziune dură exofitică sau polipoidă, trebuie suspectată o tumoră. Pentru a exclude malignitatea este necesar un examen histopatologic, iar pentru evaluarea extensiei laringiene a masei tumorale sunt necesare explorări imagistice, fie computer tomografice, fie de rezonanță magnetică nucleară [11]. 
Scopul acestui studiu a fost de a investiga aspectele clinicopatologice ale pacienților cu LNH primar al bazei limbii, diagnosticați și tratați în centrul nostru, pe o perioadă de nouă ani.

\section{Material şi metodă}

Studiul a vizat fișele electronice din evidența Departamentului de Otorinolaringologie și Chirurgie a Capului și Gâtului al Centrului Medical Rabin, din 1997 până în 2007, a zece pacienți tratați pentru LNH al bazei limbii. Au fost analizate antecedentele, simptomele și semnele de debut, mijloacele de diagnostic și rezultatele.

\section{Rezultate}

Datele clinice sunt prezentate în tabelul 1. Au fost şapte bărbați şi trei femei, cu vârsta între 17 şi 93 de ani. Trei pacienți au avut în antecedente amigdalectomie. Simptomele de debut au fost: disfagia, dispneea mai accentuată în decubit, sângerari ale cavității bucale, și formațiune tumorală cervicală (un pacient). La cinci pacienți a fost efectuată ecografia regiunii cervicale pentru a exclude o tumoră a gâtului, iar la trei o ecografie tiroidiană pentru a exclude existența țesutul tiroidian în baza limbii. Examinarea prin palpare și endoscopia indirectă au evidențiat creșterea în dimensiuni ale amigdalelor linguale; endoscopia laringiană directă rigidă a descoperit o formațiune a bazei limbii având până la 4,5x4,5 cm în diametru, dislocând posterior epiglota la 6 pacienți (figura 1). CT capului și gâtului efectuat la trei pacienți, precum și RMN efectuat la unul, au arătat o formațiune în baza limbii, care îngustează căile aeriene, fără extensie laringiană (figura 2, 3).

Tratamentul a constat din chimioterapie, radioterapie, sau o combinație între ele. Toți pacienții au intrat în remisie completă la o urmărire de până la nouă ani.

\section{Examenul histopatologic}

Toți pacienții au fost supuși unei biopsii; pacienților cu formațiune tumorală cervicală li s-a efectuat o aspirație cu ac fin. Endoscopic a fost efectuată biopsia excizională (endoscopie laser în trei cazuri). Un pacient a necesitat multiple biopsii (patru) înainte de confirmarea diagnosticului. Fragmentele biopsice au fost fixate cu formalină și incluse în parfină pentru examinarea în colorația convențională hematoxilină-eozină.

Toate probele au fost supuse analizei imunohistochimice pentru markerii CD20, CD79A, Bcl2, LN1 (CD75) și LN2 (CD74), precum și pentru virusul Ebstein-Barr și expresia antigenelor asociate celulelor T (CD3, CD43, și CD45RO).

Examenul histopatologic a evidențiat un limfom difuz cu celule B mari la opt pacienți. Tumora înlocuia arhitectura normală printr-un pattern difuz. Au fost identificate celule limfoide medii spre mari, majoritatea cu nuclei lobulați cu doi până la patru nucleoli; în două cazuri au fost observate celule cu un singur nucleol, dar cu aspect ,imunoblastic”. Toate probele prezentau expresia markerilor B CD20 și CD79A. O probă a fost caracterizată de un pattern nodular mediu, fiind pozitivă imunohistochimic pentru Bcl2, LN1 (CD75), și LN2 (CD74). A fost sugerată o posibilă origine a celulelor din centrii foliculari. La o probă a unui alt pacient (cel mai tânăr din serie, având 17 ani) au fost identificați numeroși corpi de tip macrofagic și o înaltă rată a apoptozei, ceea ce a sugerat inițial diagnosticul de „limfom Burkitt atipic”. Toate probele au avut un index proliferativ de $80-90 \%$, fiind negative pentru virusul Ebstein-Barr.

Celelalte două cazuri au fost diagnosticate la examenul histopatologic cu limfom cu celule T periferice. Masa tumorală prezenta un infiltrat difuz cu o populație celulară mai heterogenă decât limfomul difuz cu celule B mari și predominanța celulelor medii sau mari. Nucleii erau neregulați și veziculari, cu nucleoli proeminenți, pe fondul unor celule plasmatice, histiocite și eozinofile. La periferia leziunilor au fost semnalați câțiva foliculi limfoizi reactivi, cu o proliferare a venulelor postcapilare, precum și fibroză marcată. Probele ambilor pacienți au fost pozitive pentru antigenele asociate 
celulelor T CD3, CD43 și CD45RO și negative pentru virusul Ebstein-Barr. Indexul de proliferare a fost de $35 \%$, predominant în celulele mari.

\section{Discuții}

Am descris aspectele clinicopatologice la zece pacienți cu LNH la baza limbii, care au fost tratați în departamentul nostru într-o perioadă de nouă ani.

Limfoamele non-hodgkiniene sunt cele mai frecvente neoplazii nonepiteliale ale capului şi gâtului [12], neavând semne și simptome patognomonice $[13,14,15,16]$. LNH ale bazei limbii pot apare primar, sau ca diseminări secundare [1]. Deoarece limba este situată superficial, majoritatea leziunilor limbii pot fi ușor observate și diagnosticate, fără analiză imagistică. Totuși, unele pot apare în porțiunile profunde ale limbii ca și tumefieri submucoase, fiind necesare studii imagistice cros-secționale pentru a le identifica natura și extensia reală [17]. În acest studiu au fost investigate tumori ale planurilor țesuturilor moi ale gâtului și bazei limbii. La trei pacienți au fost efectuate examinări CT pentru evaluarea extensiei locale.

Un pacient a prezentat o hemoragie masivă neobișnuită provenind din limfomul inelului Waldeyer, așa cum dealtfel a fost descrisă de Turner și Zitsch [18].

Î́n 2001, Daskalopoulou și colab. [19] au diagnosticat limfoame ale inelului Waldeyer la 17 pacienți utilizând biopsia cu aspirație cu ac fin, totuși în două cazuri au fost observate diferențe histologice în tipurile specifice de limfom.

La pacienții care prezintă dispnee progresivă, examinarea bazei limbii ar trebui să constituie prima măsură în investigarea căilor aeriene. Dacă căile aeriene nu sunt aceesibile examinării, iar pacientul este în detresă respiratorie, clinicianul trebuie să se consulte cu un anestezist înainte de tentativa chirurgicală. Recomandăm biopsia diagnostică și nu aspirația cu ac fin, uneori fiind necesare biopsii multiple, precum la unul din cazurile noastre.

Prezentarea clinică similară a limfomului cu a carcinomului inelului Waldeyer face examinarea histologică esențială pentru diagnostic. Întradevăr, ambele tipuri de tumori se pot prezenta ca mase tumorale ale gâtului [20], precum la unul din cazurile noastre.

Limfomul difuz cu celule B mari este cel mai comun tip de LNH în țările vestice, reprezentând aproximativ 30\% din toate cazurile de LNH. O treime până la o pătrime din limfoamele difuze cu celule B mari au o origine primară extranodulară [5]. Limfomul difuz cu celule B mari a fost în seria noastră diagnosticul histologic comun (8 pacienți), în concordanță cu alte studii [2-4].

În ceea ce privesc caracteristicile generale, limfomul inelului Waldeyer este considerat ca o boală a vârstnicului, $80 \%$ din cazuri fiind la peste 50 ani $[4,20]$, cu o predominanță a bărbaților [1]. În lotul nostru, cu excepția a doi pacienți, restul au fost peste 50 ani, iar şapte din zece au fost bărbați $(66.6 \%)$.

În concluzie, pacienții cu o suspiciune de tumoră a bazei limbii, care prezintă disfagie şi/sau dispnee progresivă, în special în decubit dorsal, trebuie investigați pentru un limfom malign. Deși LNH al bazei limbii este neobișnuit, el nu trebuie omis în investigație. Apare mai degrabă la vârstnici (peste 50 ani), dar poate apare şi la tineri. Diagnosticul include palparea masei tumorale dacă este accesibilă, fibrolaringoscopia indirectă sau directă şi explorarea ecografică a gâtului pentru excluderea tumorii, localizarea glandei tiroide şi examinarea ei când se suspicionează resturi tiroidiene linguale, precum şi CT şi RMN ale laringofaringelui pentru evaluarea extensiei tumorale. Examinarea histopatologică este crucială pentru confirmarea diagnosticului, uneori fiind necesare mai multe biopsii. 


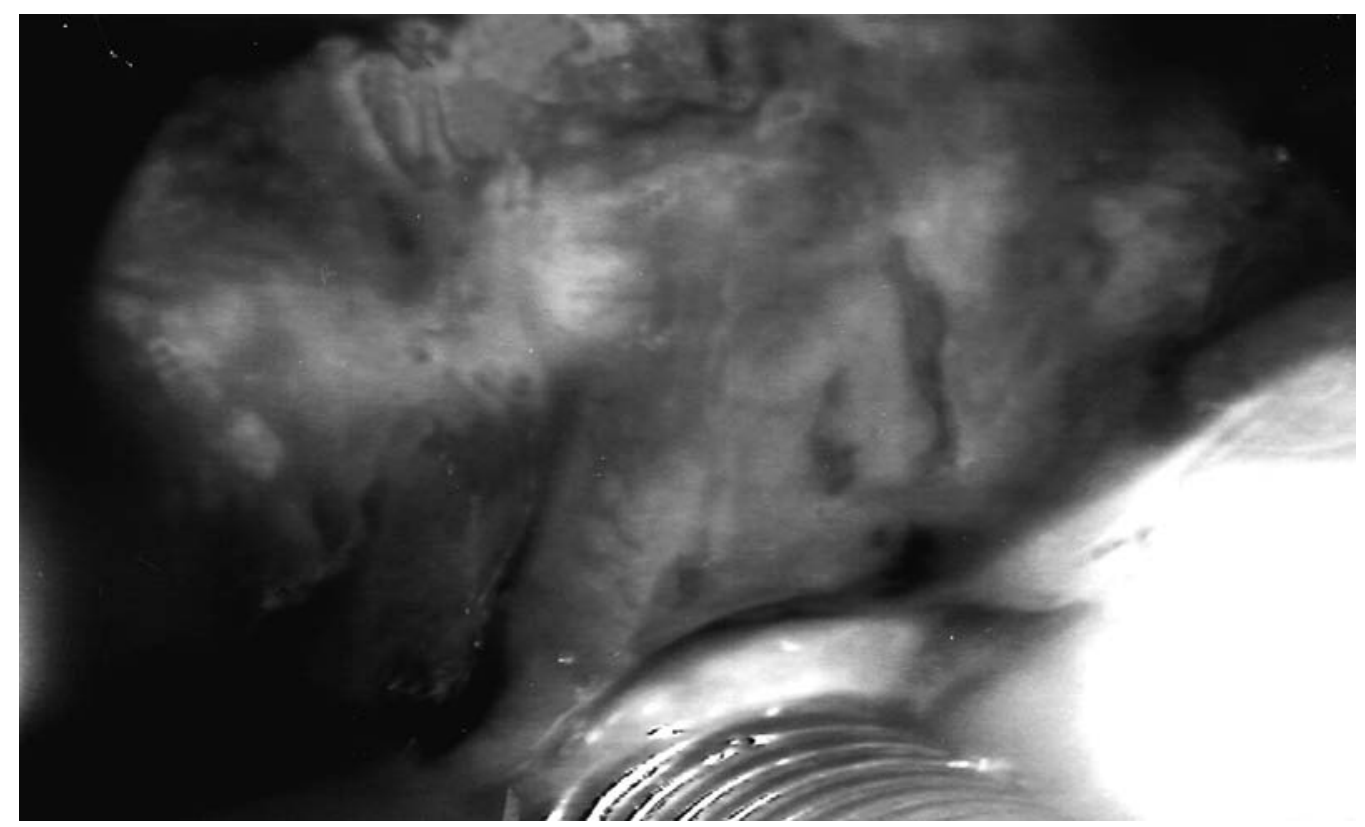

Fig. 1 Clinical presentation of base-of-tongue NHL in intubated 66-year-old man (Prezentare clinică a LNH al bazei limbii la un bărbat de 66 ani, intubat)

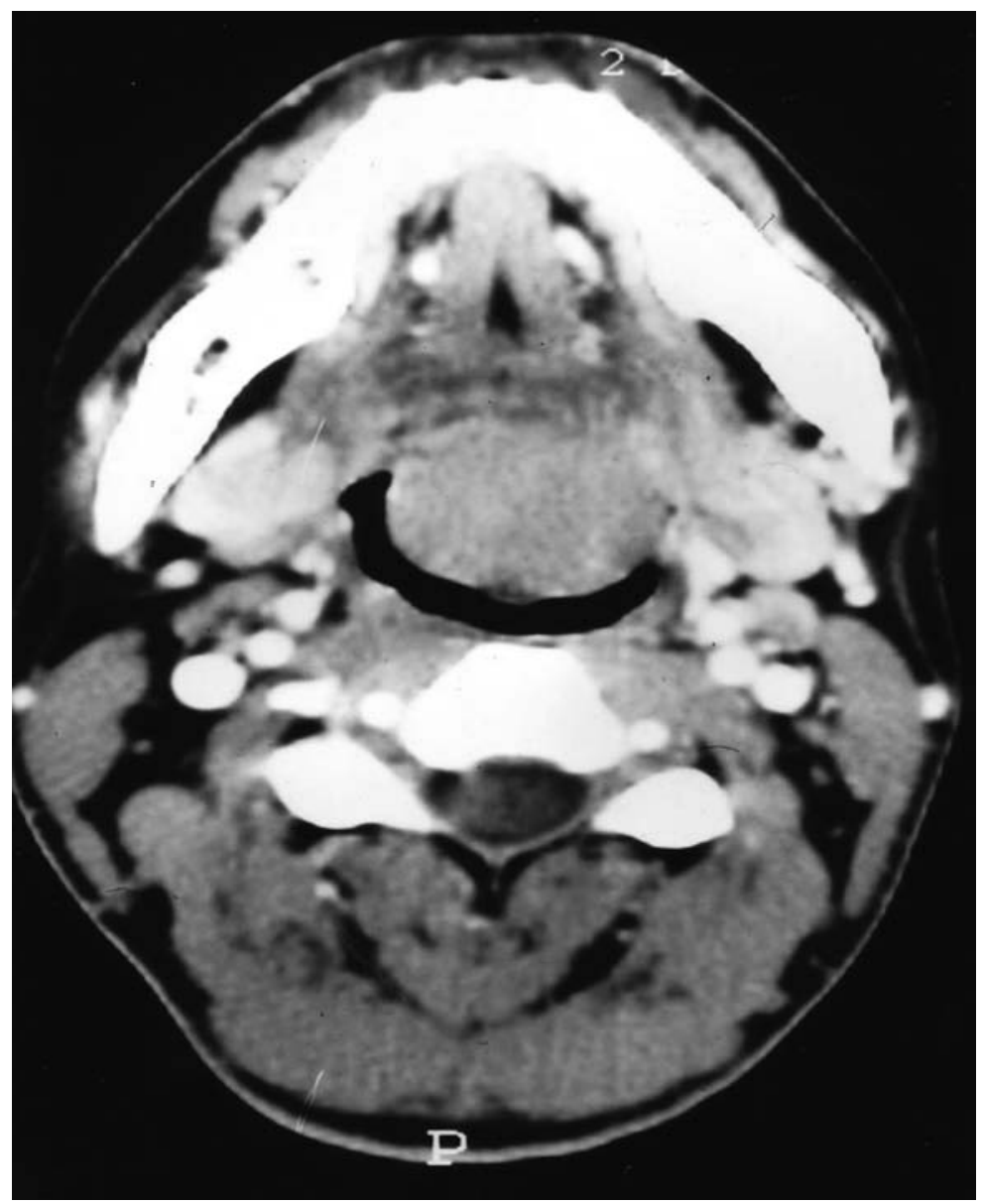

Fig. 2 Axial CT scan showING huge mass in the base of the tongue of a 28-year- old man (CT axial arătând o formațiune masivă în baza limbii la un bărbat de 28 de ani) 


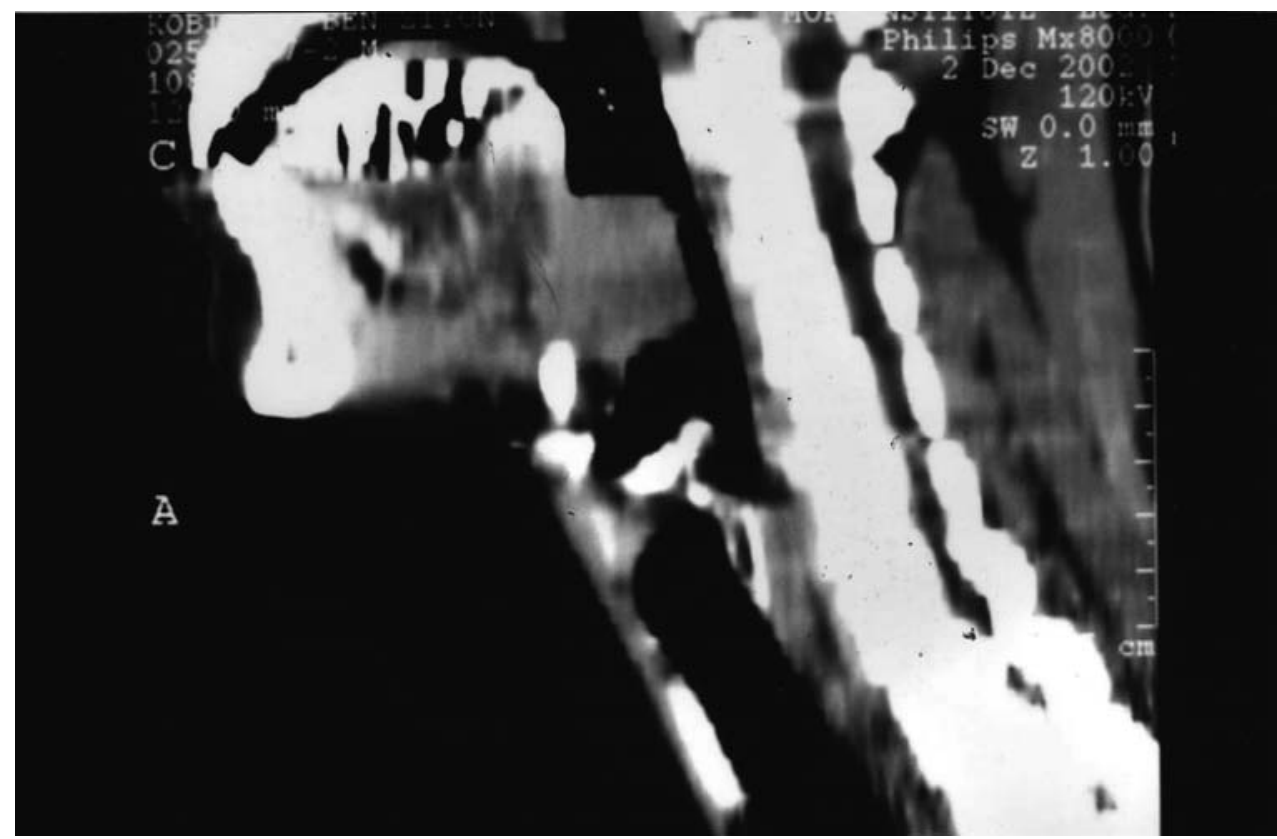

Fig. 3 Sagittal CT scan showing mass in the base of the tongue of a 28-year-old man (CT sagital arătând masa tumorală în baza limbii la un bărbat de 28 ani)

Table (Tabel) 1: Symptoms, signs, and radiological and findings in ten patients with non-Hodgkin's lymphoma of the tongue base. (Simptome, semne şi rezultatele radiologice la zece pacienți cu LNH al bazei limbii)

\begin{tabular}{|c|c|c|c|c|c|c|c|c|c|c|}
\hline Characteristics (caracteristici) & \multicolumn{10}{|c|}{ Patients (pacienți) } \\
\hline & 1 & 2 & 3 & 4 & 5 & 6 & 7 & 8 & 9 & 10 \\
\hline Sex & M & $\mathrm{M}$ & $\mathrm{F}$ & $\mathrm{M}$ & $\mathrm{F}$ & $\mathrm{M}$ & $\mathrm{M}$ & $\mathrm{M}$ & $\mathrm{M}$ & $\mathrm{F}$ \\
\hline $\begin{array}{l}\text { Age (yr) } \\
\text { Vârsta (ani) }\end{array}$ & 74 & 66 & 59 & 28 & 88 & 17 & 54 & 65 & 93 & 81 \\
\hline $\begin{array}{l}\text { Symptoms } \\
\text { Simptome }\end{array}$ & & & & & & & & & & \\
\hline $\begin{array}{l}\text { Dysphagia } \\
\text { Disfagie }\end{array}$ & Yes da & & - & - & - & Yes da & Yes da & Yes da & Yes da & Yes da \\
\hline $\begin{array}{l}\text { Dyspnea } \\
\text { Dispnee }\end{array}$ & - & Yes da & Yes da & Yes da & Yes da & - & Yes da & - & - & - \\
\hline $\begin{array}{l}\text { Mouth bleeding } \\
\text { Sângerarea orală }\end{array}$ & - & - & - & - & - & - & - & - & Yes da & - \\
\hline $\begin{array}{l}\text { Neck mass } \\
\text { Tumoră a gâtului }\end{array}$ & - & - & - & - & - & - & Yes da & - & - & - \\
\hline $\begin{array}{l}\text { Endoscopy } \\
\text { Endoscopie }\end{array}$ & & & & & & & & & & \\
\hline $\begin{array}{l}\text { Tongue mass }(\mathrm{cm}) \\
\text { Tumora limbii }\end{array}$ & $3 \times 3$ & $2 \times 2$ & Sup & $3 \times 3$ & Sup & $3 \times 3$ & $2 \times 2$ & $2 \times 2$ & $3 \times 3$ & $4 \times 4$ \\
\hline $\begin{array}{l}\text { Epiglottis displacement } \\
\text { Deplasarea epiglotei }\end{array}$ & - & Yes da & - & Yes da & - & Yes da & Yes da & - & Yes da & Yes da \\
\hline $\begin{array}{l}\text { Imaging } \\
\text { Imagistică }\end{array}$ & & & & & & & & & & \\
\hline $\begin{array}{l}\text { Ultrasound } \\
\text { Ecografie }\end{array}$ & Yes da & Yes da & Yes da & Yes da & - & Yes da & - & - & - & - \\
\hline CT scan & - & - & Yes da & Yes da & - & - & Yes da & - & - & - \\
\hline Thyroid scan & Yes da & - & Yes da & Yes da & - & - & - & - & - & - \\
\hline $\begin{array}{l}\text { MRI } \\
\text { RMN }\end{array}$ & - & - & - & - & - & - & - & - & - & Yes da \\
\hline $\begin{array}{l}\text { No. biopsies } \\
\text { Nr. biopsii }\end{array}$ & 2 & 4 & 1 & 1 & 1 & 1 & 1 & 1 & 1 & 1 \\
\hline
\end{tabular}

Traducere: dr Bumbuluț Călin 


\section{References (Referințe)}

1. Gurkaynak M, Cengiz M, Akyurek S, Ozyar E, Atahan IL, et all. Waldeyer's ring lymphomas: treatment results and prognostic factors. Am J Clin Oncol 2003;26:437-440.

2. Goteri G, Ascani G, Filosa A, Rubini C, Olay S, et all. Primary malt lymphoma of the tongue. Med Oral Patol Oral Cir Bucal 2004;9:461-463;459-461.

3. Bajetta E, Buzzoni R, Rilke F, Valagussa P, Valagussa P, et al. Non-Hodgkin's lymphomas of Waldeyer's ring. Tumori 1983;69:129-136.

4. Ezzat AA, Ibrahim EM, El Weshi AN, Khafaga YM, AlJurf M, et all. Localized non-Hodgkin's lymphoma of Waldeyer's ring: clinical features, management, and prognosis of 130 adult patients. Head Neck 2001;23:547-558.

5. Lopez-Guillermo A, Colomo L, Jimenez M, Bosch F, Villamor N, et all. Diffuse large B-cell lymphoma: clinical and biological characterization and outcome according to the nodal or extra nodal primary origin. J Clin Oncol 2005;23:2797-2804.

6. Zucca E, Bertoni F, Roggero E, Cavalli F. The gastric marginal zone B-cell lymphoma of MALT type. Blood 2000;96:410-419.

7. Zucca E, Roggero E, Bertoni F, Conconi A, Cavalli F. Primary extranodal non-Hodgkin's lymphomas. Part 2: Head and neck, central nervous system and other less common sites. Ann Oncol 1999;10:1023-1033.

8. Aviles A, Delgado S, Ruiz H, de la Torre A, Guzman R, et all. Treatment of non-Hodgkin's lymphoma of Waldeyer's ring: radiotherapy versus chemotherapy versus combined therapy. Eur J Cancer B Oral Oncol 1996;32B:19-23.

9. Tan LH. Lymphomas involving Waldeyer's ring: placement, paradigms, peculiarities, pitfalls, patterns and postulates. Ann Acad Med Singapore 2004;33:15-26.

10. Batuecas Caletrio A, Gomez Gonzalez JL, Munoz Herrera A, Blanco Perez P, Serradilla Lopez JM, et al. Non-Hodgkin's lymphoma in the ENT field. Acta Otorrinolaringol Esp 2005;56:215-218.

11. Dundar A, Ozunlu A, Sahan M, Ozgen F. Lingual tonsil hypertrophy producing obstructive sleep apnea. Laryngoscope 1996;106:1167-1169.

12. Weber AL, Rahemtullah A, Ferry JA. Hodgkin and non-Hodgkin lymphoma of the head and neck: clinical, pathologic, and imaging evaluation. Neuroimaging Clin North Am 2003;13:371-392.

13. Shindoh M, Takami T, Arisue M, Yamashita T, Saito T, et all. Comparison between submucosal (extra-nodal) and nodal non-Hodgkin's lymphoma (NHL) in the oral and maxillofacial region. J Oral Pathol Med 1997;26:283-289.

14. Soderholm AL, Lindqvist C, Heikinheimo K, Forssell K, Happonen RP. Non-Hodgkin's lymphomas presenting through oral symptoms. Int J Oral Maxillofac Surg 1990;19:131-134.

15. Wolvius EB, van der Valk P, van der Wal JE, Van Diest PJ, Huijgens PC, et al. Primary extranodal nonHodgkin lymphoma of the oral cavity. An analysis of 34 cases. Eur J Cancer B Oral Oncol 1994;30:121-125.

16. Castellano S, Carbone M, Carrozzo M, Brocoletti R, Pagano M, et al. Onset of oral extranodal large B-cell nonHodgkin's lymphoma in a patient with polycythemia vera: a rare presentation. Oral Oncol 2002;38:624-626.

17. Kim SH, Han MH, Park SW, Chang KH. Radiologic-pathologic correlation of unusual lingual masses: Part II: benign and malignant tumors. Korean J Radiol 2001;2:42-51.

18. Turner $\mathrm{L}, \mathrm{Zitsch} \mathrm{R}, 3^{\text {rd }}$. Waldeyer's ring lymphoma presenting as massive oropharyngeal hemorrhage. Mo Med 2000;97:63-65.

19. Daskalopoulou D, Papanastasiou C, Markidou S, Rapidis AD. The diagnostic value of fine needle aspiration cytology in Waldeyer's ring lymphomas. Oral Oncol 2001;37:36-41.

20. Jacobs C, Hoppe RT. Non-Hodgkin's lymphomas of head and neck extranodal sites. Int J Radiat Oncol Biol Phys 1985;11:357-364 